\title{
Developing English for Specific Purposes (ESP) Textbook for Pharmacy Students Using On-Line Teaching in Higher Education
}

\author{
Abd. Syakur ${ }^{1}$, Esti Junining ${ }^{2}$, M. Khusni Mubarok ${ }^{1}$, Margarana $^{3}$ \\ ${ }^{1}$ Department of Graduate Program of English Education, STKIP PGRI Sidoarjo, Indonesia \\ 2Doctoral Environmental Assessment and Development Program, Universitas Brawijaya, Indonesia \\ ${ }^{3}$ Department of Graduate of English Education, Universitas Negeri Yogyakarta, Indonesia \\ Email: syakurabdmpd@gmail.com
}

\begin{abstract}
The purpose of this developmental research is to create ESP learning textbooks for Diploma three (D3) Pharmacy students at the Surabaya Pharmacy Academy, to determine the textbooks' feasibility, and to ascertain students' responses to the ESP textbooks. The ADDIE Research and Development (RED) model is used in this study. This ESP textbook was created in response to the study's findings. The feasibility study of the ESP textbook reveals the following points: 1) The Diploma three (D3) Pharmacy program's material experts and lecturers assign a percentage of 53.33 percent below the range of 85.94 percent, indicating that the development of digital-based textbooks receives a "A" grade and falls into the "Very Good" category. 2) Media and digital experts with online learning as well as Pharmacy diploma three (D3) study programs provide a percentage of 53.33 percent less than the 85.94 percent range, indicating that developed digital-based textbooks receive a "A" and are classified as "Very Good." 3) Student comprehension, as measured by questionnaires, also received a favorable response of 53.33 percent in the range of 85.94 percent, indicating that the development of digital-based textbooks received a "A" or "Very Good " grade. The interviews revealed that students responded positively to digital-based ESP textbooks. In summary, the ESP textbook for Pharmacy students in the Diploma three (D3) department is acceptable which can be used as an online learning medium for english Teaching.
\end{abstract}

Keywords: English for Specific Purposes (ESP); books of texts; online teaching

\section{Introduction}

Development in the pharmaceutical world today is highly regarded by the public and various groups and pharmacy study programs as a profession that cannot be separated from efforts to consolidate the three main pillars of professions such as education, service, and professional life (Antony et al., 2015). There have been several attempts made to improve the quality of education by developing a standard curriculum in accordance with the development of science and technology (Mayfield, 2011; Shah et al., 2011; Wats and Wats, 2009). English has become one of the main determinants of the quality of pharmaceutical services, because English courses are the core curriculum set by the Indonesian government. Therefore, the importance of ensuring the quality of education must be realized by all stakeholders related to efforts to answer the needs of the community in the world, especially in Indonesia. A form of quality assurance is the analysis and evaluation of English language materials (textbooks) and curricula adapted to the Indonesian National Qualification Framework (INQF / KKNI) and the Indonesian National Standard of Higher Education (SN-Dikti) in 2015 as the development of sustainable science and technology now.

This paradigm wants to encourage humans to consider the sustainability of the planet Earth as well as the sustainability of the entire universe. WCED (World Commission on Environment and Development) provides Recognition that sustainable development overall 
requires change in the value of attitudes towards the environment and development, As a result, education can play a critical role in achieving sustainability. In 2011, the Ministry of National Education adopted the concept of sustainable development as the foundation for national education in Indonesia, which is a sustainable concept that serves as one of the fundamental principles for developing Indonesian education. This is reflected in the Educational Legislation and the Ministry Education's 2010-2014 National Strategy, which recognise Academic achievement for Development, Innovation, and/or Sustainable as a national paradigm for academic reform.

As a consequence, education has the potential to be a critical component of achieving sustainable development. In 2011, the Ministry of National Education included the concept of education for sustainable development as a framework for national education in Indonesia, which is a sustainable concept that helps as one of the fundamental principles for developing national education. This is reflected in the National Education Law and the Ministry of National Education's 2010-2014 Strategic Plan, which would include Education for Development, Development, and/or Sustainability as a national educational development approach.

ESP has not gained wide acceptance among Indonesian English instructors, particularly at the college or university level. This is demonstrated by the fact that non-English departments assign only 2-4 credits to English courses in the first or second semesters. This could be one of the reasons English instructors are disinclined to teach ESP. However, workplace ESP that is more EOP in nature is in high demand. Universities require graduates to obtain not only a certificate upon completion of courses, but also a graduate diploma attesting to their competence. This means that universities, as well as vocational colleges and polytechnics, must recognize ESP.

While attending colleges and universities, on the basis of casual examinations of public correspondence "reading in the case of EAP is the language skill which is mostly taught at nonEnglish departments in the graduate and the undergraduate levels. The courses are offered in the first or the second semesters". The aim of education reading by text book is to create study skills with the ultimate goal of expanded students' academic knowledge in the fields those who study.

The advancement of technology, communication, and information, particularly the internet, has provided a platform for teachers in Indonesia to be able to utilize it as a source of positive educational media to assist in the teaching and learning processes. Teachers and students benefit from use of technology media by gaining access to educational materials and interacting directly in the classroom, as well as outside the classroom via online media (Prasasti, et al: 2019).

Higher education is one of the educational institutions in the national education system. Higher education institutions are needed to undertake education, research, and voluntary work in accordance with the provisions of Law No. 20 of 2003 on the National Education Policy (Depdiknas, 2003). The main aim of higher education is to facilitate student learning in order to carry out its obligations, tertiary institutions must be supported by synergistic cooperation from all universities (Hamid K, et al: 2019)

The existence of e-learning has a big influence on the learning process. Even many universities that have used e-learning as a tool so that the teaching and learning process can still be carried out without the need of facing each other from both parties. So that the difficulties in the learning process that have only been fixated on meetings in the classroom can be resolve by utilizing the e-learning. For example, when there are limitations to the classroom or time, in which leads to the absence of learning process that should be held (Hutagalung, 2018). 
ESP can be taught in the study program and one of them is in the Diploma three (D3) Pharmacy department as it has been done in previous research both nationally and internationally (Shah et al., 2011). Learning with continuous and continuous innovation can help students quickly for the time being online learning by referring to Education for Sustainable Development (ESD) to have creativity in thinking, solving problems, and interacting and helping in learning that leads to solving real problems.

On the other hand the education system consists of five important components (students, lecturers, materials (textbooks), online-based teaching methods, and evaluations which are closely related. Textbooks for three diploma study programs (D3) Pharmacy in higher education are designed to provide opportunities to develop students' English competence that includes reading skills, speaking skills, and writing skills in a more communicative and meaningful way with online learning models (Henard and Roseveare, 2012; Shah et al., 2011).

Online platforms, also known as E-learning, is a form of distance education that can be accessed in a variety of ways. Students are no longer required to be in the same room as education used to be. Students can access online learning from any location and at any time (Robles, 2012). Wi-Fi connectivity is required for learning to take place. Other student benefits are easily, flexibly, quickly, and accurately accessible to anyone. The application of internet-based e-learning technology to education must be developed as one of the technologies in the use of instructional media and learning resources in this era, so that students will see more than textbooks.

Researchers discovered several issues with Pharmacy Diploma 3 (D3) students, particularly when studying English for Special Purposes (ESP). The issue is that students lack vocabulary, their mastery of vocabulary is still low, the majority of students have a low motivation to learn, and students struggle to translate pharmaceutical terms into English. Additionally, students struggle to learn English (ESP) because the textbooks they use contain only exercises and lack explanations, despite the fact that they are online (Sulam et al., 2019).

The researchers chose to develop textbooks based on online learning media that allow students to practice and improve their English independently based on their identification of the problems above. It is hoped that by conducting this study, it will assist students in learning English more easily and successfully in the millennial era.

\section{Research Methods}

This research is based entails methods of research and development (R\&D), as well as research methods used to pique students' interest in learning English through the use of core guidelines from digitalized textbooks in diploma three (D3) Pharmacy departments, ranging from vocabulary mastery in pharmaceutical science to English language proficiency. The purpose of this research is to develop English language media products in the digital textbooks. The ADDIE model was used to develop this research. The ADDIE model is a design learning model comprised of five level: analysis, design, development, implementation, and evaluation. The research procedure used in this research and development is as follows: Dick and Carry's (Mayfield, 2011) ADDIE model is used: 


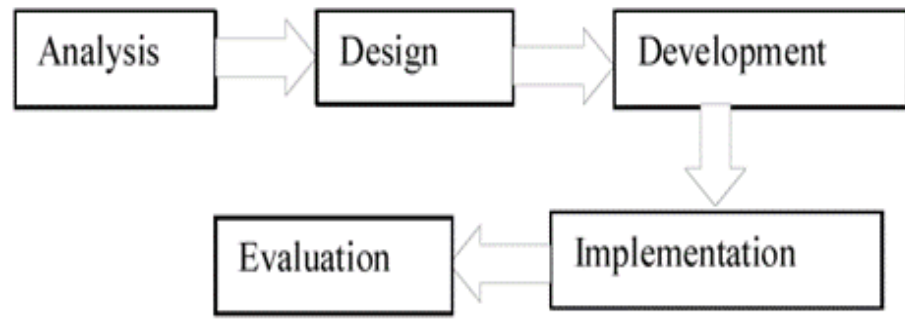

Figure 1. Phases of the ADDIE model

First: Analysis phase, researchers do need analysis to find out the needs of students and diploma study program (D3) of Pharmacy Surabaya Pharmacy Academy, Brainstorming products and conduct needs analysis in lessons and identify learning content / material in the textbook that will later be online and objective formulation. Second: in the design phase, researchers in this phase prepare the concepts and structure of the module framework that will be online in a piece of software. Third: in the development phase, the researcher starts an action including (1). Development of textbooks, (2) Validation is carried out by media and IT experts, (3) material experts, (4) lecturers and (5) Measurement of products to be produced. Fourth: the implementation phase, student assessment of digital based textbooks that are online on a software.

Finally: an evaluation is carried out to measure the success of using digital-based text that is online on a software using a questionnaire. The participants in this study were lecturers and students from the Surabaya Pharmacy Academy's Diploma (D3) Pharmacy departments, including lecturers, material experts, media experts, and IT experts, lecturers majoring in English education in Pharmacy Academy (there were 60 students). The method for obtaining data, the following are used:

\section{Questionnaire}

A questionnaire is a data collection technique in which respondents were asked to respond to a series of questions or written statements. A questionnaire was written statement used to obtain information or matters relating to student responses to learning English in an online format using digital-based textbooks for mastering English terms in pharmacy using digital-based textbook media as a source of independent learning. This study's data was collected through a questionnaire that included the following items:
a. A Questionnaire for material experts and Pharmacy D3 departments
b. Questionnaire for media and IT experts
c. Questionnaire for D3 Pharmacy lecturers
d. Questionnaire for first semester students

\section{Interview}

Interviews were conducted to assess previous media effects and to determine student interest in learning English online through the use of digital-based textbooks for mastering English terms in pharmacy. Interviews are also used as a guide to request material to be summarized in the media textbooks / modules. Alternative responses make use of the Likert Scale provided with either the media efficacy questionnaire, which contains 5 alternative responses: very good, good, neutral, and lacking Table 1. 
Table 1. Criteria for evaluating items on the media eligibility questionnaire

\begin{tabular}{lc}
\hline Criteria & Scoring \\
\hline Very Good & 5 \\
Good & 4 \\
Fair & 3 \\
Less & 2 \\
Poor & 1 \\
\hline
\end{tabular}

The steps to analyze the online media quality data ESP Module are:

a. A change in the qualitative value becomes quantitative using a Likert Scale with the provisions in Table 2, as follows:

Table 2. Changes in qualitative data into quantitative data

\begin{tabular}{lc}
\hline Criteria & Scoring \\
\hline Very Good & 5 \\
Good & 4 \\
Fair & 3 \\
Less & 2 \\
Poor & 1 \\
\hline
\end{tabular}

b. Then the data collected is analyzed by calculating the average score obtained by the formula:

$$
\text { Information: } \quad \begin{aligned}
\bar{x}= & \frac{\sum x}{n} \text { and } S d=\sqrt{\frac{\sum(x-\bar{x})^{2}}{n-1}} \\
& \mathrm{X}: \text { Average } \\
& \mathrm{X} \text { : Total sample } \\
& \text { n: Number of samples } \\
& \text { SD: Standard deviation }
\end{aligned}
$$

c. Using the ideal conversion guidelines described in the following table, the results of the average evaluation are converted back into qualitative analysis in the feasibility category of digital-based textbooks, allowing conclusions about the feasibility of digital-based textbooks for mastering English terms in pharmacy with Software.

\section{Student Response Data}

Student responses to digital-based textbooks for mastering English terms in pharmacy were collected from 60 students who completed a 20 -question questionnaire. The responses of these students were classified as follows: $1=$ Very good with a score of 85-94, 2 = good with a score of 75-84, $3=$ Fair with a score of $65-74,4=$ Less with a score of 55-64, $5=$ Poor with a score of 45-54. Very good and good are considered positive and analyzed further (Table 3). Meanwhile, Fair, Less, and Poor belong to negative responses. Positive student responses are defined as those in which the average proportion of students responding is approximately equivalent to $60 \%$. 
Table 3. The frequency distribution of respondents' responses to products

\begin{tabular}{cccl}
\hline No. & Score & Criteria & Information \\
\hline 1 & $85-94$ & A & VeryGood \\
2 & $75-84$ & B & Good \\
3 & $65-74$ & C & Fair \\
4 & $55-64$ & D & Less \\
5 & $45-54$ & E & Poor \\
\hline
\end{tabular}

\section{Discussion}

In the research of the discussion to be elaborated namely to determine the feasibility of digital-based textbooks for mastering the English term in pharmacy that was developed, it was carried out through several validation processes by several experts. The responses to the questionnaire are summarized in Table 4.

Table 4. Results of the frequency distribution of respondents' values

\begin{tabular}{cccl}
\hline No. & Score & Criteria & Information \\
\hline 1 & 53,33 & $\mathrm{~A}$ & Very good \\
2 & 28,33 & $\mathrm{~B}$ & Good \\
3 & 8,33 & $\mathrm{C}$ & Fair \\
4 & 6,67 & $\mathrm{D}$ & Less \\
5 & 3,33 & $\mathrm{E}$ & Poor \\
\hline
\end{tabular}

The suitability of a good or service for a module is decided by material experts, media and information technology experts, and lecturers from Surabaya Pharmacy Academy's diploma three (D3) pharmacy departments. After that, a digital-based textbook revision process was carried out with D3 Pharmacy students. The result of this process is the decision whether digital based textbooks are feasible to be tested in the field or not. After that digital based textbooks were implemented among the second semester diploma three (D3) Pharmacy department's students. Field trials were conducted with 60 students. Researchers introduced digital-based textbooks, explained the contents of digital-based textbooks, then explained the benefits of digital-based textbooks for learning ESP English courses for pharmacy. After that, researchers conducted teaching practices to students. The students appear to be very enthusiastic as they work through digital textbooks to master the English term in pharmacy using software.

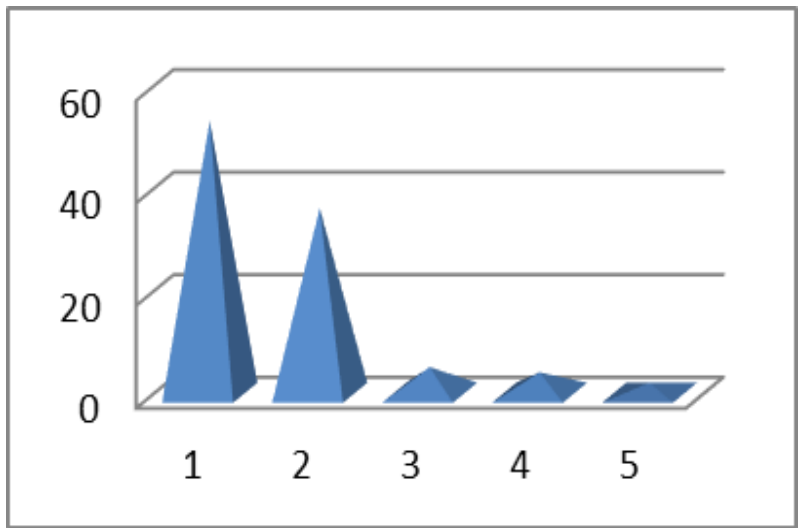

Figure 2. Results of digital-based textbook questionnaires (online learning media) 
The researcher distributed the questionnaires to 60 students that contained twenty questions. The questionnaire employs a Likert scale ranging from 1 to 5 . This function gathers information about student interest in digital textbooks. According to the questionnaire responses, students reacted positively to digital-based textbooks developed around the themes of motivation, interest, and media visualization. The percentage score is 53.33 percent, falling within the range of 60.33 percent to 28.33 percent. In conclusion, digital textbooks earned a "A" and were classified as positive.

A questionnaire with twenty questions was distributed to 60 students by the researcher. A Likert scale of 1-5 is used in the questionnaire. This function collects information about students' interest in digital textbooks. According to the questionnaire responses, students reacted positively to digital-based textbooks that were developed with motivation, interest, and media visualization in mind. The percentage score is 53.33 percent, which falls within the range of 60.33 percent to 28.33 percent. To summarize, digital textbooks received a "A" and were classified as positive.

\section{Conclusion}

On the basis of the study's findings, it can be concluded that ESP in conjunction with digital textbooks for mastering English terms in pharmacy with software for diploma (D3) Pharmacy departments' students at the Surabaya Pharmacy Academy is able to qualify and may consequently be used as a medium for English language instruction. Furthermore, it can be focused on developing English language material for diploma (D3) Pharmacy departments' students whose competencies are needed more than before as well as large pharmacy dictionaries in terms of writing, speaking, and reading and memorizing recipes by digitizing as the demands of this millennial era. For other material developers to emphasize the needs of students in the form of ESP in studies and outcomes relevant to competencies in the field of pharmacy and prescription science studied at the undergraduate, professional and pharmacy level.

\section{References}

Antony, J., Balzer, W. K., Brodke, M. H., and Kizhakethalackal, E. T. (2015). Lean higher education: successes, challenges, and realizing potential. International Journal of Quality \& Reliability Management.

Hamid K. A., Siregar T. M., Purba J., Mukmin, B. A. (2019). Evaluation of Implementation of Blanded Learning Implementation in Universitas Negeri Medan. Britain International of Linguistics, Arts and Education Journal, 1(2): 224-231.

Henard, F., and Roseveare, D. (2012). Fostering quality teaching in higher education: Policies and practices. An IMHE Guide for Higher Education Institutions, 7-11.

Hutagalung, T., Sari, D. E., and Wasilah, A. (2018). The Effectiveness of E-Learning on Students in the Teaching of Children's Literature Subject in Indonesian Language and Literature Study Program. Budapest International Research and Critics Institute (BIRCI-Journal): Humanities, 1(4): 277-281.

Mayfield, M. (2011). Creating training and development programs: using the ADDIE method. Development and Learning in Organizations: An International Journal 25, $19-22$.

Prasasti, T. I., et al. (2019). The Effectiveness of Learning Media Folklore Text of North Sumatera Based on Blended Learning by $10^{\text {th }}$ Grade Students of Vocational High School Harapan Mekar-1 Medan. Budapest International Research in Linguistics and Education Sciences (BirLE) Journal, 2(4): 480-490.

Robles, M. M. (2012). Executive perceptions of the top 10 soft skills needed in today's workplace. Business communication quarterly 75, 453-465. 
Shah, M., Lewis, I., and Fitzgerald, R. (2011). The renewal of quality assurance in Australian higher education: the challenge of balancing academic rigour, equity and quality outcomes. Quality in Higher Education 17, 265-278.

Sulam, K., Syakur, A., and Musyarofah, L. (2019). The Implementation of 21St Century Skills AsThe New Learning Paradigm to The Result Of Student's Career And Life Skills. Magister Scientiae 2, 228-237.

Wats, M., and Wats, R. K. (2009). Developing Soft Skills in Students. International Journal of Learning 15. 